\title{
3 Verortung der iranischen Diaspora
}

How then has this group of religiously, ethnically, and linguistically diverse people with different pasts constructed an Iranian identity in diaspora? Why is Iranian immigration even termed a diaspora? (Mostofi, „Who We Are“ 685)

Dieses Kapitel zielt darauf ab, eine raum- und kulturtheoretische Perspektive zu entwickeln, die erstens das Verhältnis von Diaspora Studies und Film miteinbezieht und die zweitens die im vorangegangenen Kapitel umrissene filmtheoretische Dimension des iranischen Diasporafilmes greifbar machen soll. Zwar wird in jüngster Zeit verstärkt das Verhältnis von Diaspora und iranischer Kulturproduktion aus medienwissenschaftlicher Sicht untersucht, doch spielt dabei die von Nilou Mostofi aufgeworfene Frage: „Why is Iranian immigration even termed a diaspora?“ (685) keine explizite Rolle. Ziel dieses Kapitels ist es daher, mit raum- und kulturtheoretischen Ansätzen ein Diasporakonzept zu erarbeiten, welches das Verhältnis von Diaspora und Film aus medientheoretischer Sicht reflektiert und die variable Bedeutung der Kategorie ,iranische Diaspora“ für die spezifischen filmischen Räume des iranischen Diasporafilmes in einem konkreten Kontext fassbar macht. 


\subsection{Diaspora und Raum}

Bei der Erforschung von Diaspora ist quer durch die Disziplinen die Raumfrage beständig virulent, denn der Diaspora ist die Auseinandersetzung mit Raum grundlegend eingeschrieben: Von der Zerstreuung von einem Ort an einen beziehungsweise mehrere andere - durch die Rückbindung an jenen Ursprungsort bis hin zur Erfahrung am neuen Ort wird Diaspora in den Diskursen der Diaspora Studies immer räumlich gedacht. Der Historiker James Clifford verweist auf den Begriff selber als „a travelling term“ (302), beschreibe er doch wörtlich oder metaphorisch Migration, Rückkehr, Verbreitung, Grenzüberschreitung und Multi-Lokalität und damit immer zugleich ein Hier-Sein und Weg-Sein. Auch Robin Cohen und Steven Vertovec betonen die zentrale Bedeutung von einem mehrdimensionalen Verständnis von Raum und Bewegung, welches sich nicht auf die tatsächliche physische Migration beschränkt, sondern Platz für diskursive, kulturelle, virtuelle und sozial vernetzte Räume schafft. Peter Jackson, Philip Crang und Claire Dwyer, ihres Zeichens Geograph_innen, sprechen sich ebenfalls für Diaspora als räumlichen Begriff aus:

\section{Different diasporas are characterized by different geogra- phies that go beyond simple oppositions between the na- tional and the transnational, the rooted and the routed, the territorial and the deterritorialized. Diaspora is not only an inherently spatial term. Its particular historical forms evi- dence particular and distinctive spatialities. (2)}

Für die Beschäftigung mit dem Begriff der Diaspora sind es insbesondere die Schichtungen verschiedener kultureller Zuschreibungen im Migrationskontext, welche den Raumdiskurs laut der Kulturwissenschaftlerin Doris BachmannMedick relevant machen: 
[D]ie zunehmend entterritorialisierten Raumverhältnisse und Beziehungsgeflechte haben auch das Raumverständnis transnationalisiert. Erst dadurch ist etwa das Phänomen zu erfassen, dass Diasporagruppen weltweit vernetzt sind und gemeinsame kulturelle Vorstellungen teilen, dabei aber doch in verschiedene Lokalitäten zerstreut sind. (295)

Die verstärkte Aufmerksamkeit und Beschäftigung mit Raum in historischen und kulturellen Kontexten ist eine Entwicklung, die sich im sogenannten spatial turn niedergeschlagen hat (Bachmann-Medick 284-316). Den Kern dieser wissenschaftlichen Herangehensweise bildet nicht die Frage, wie Raum geschichtsbildend wirkt, sondern vielmehr, wie Raum durch Geschichte, Kultur et cetera erst produziert wird. Der Soziologe Henri Lefebvre geht in seinem 1974 veröffentlichten Text La production de l'espace von dem Grundgedanken aus, dass Raum als Produkt sozialer Handlungen entsteht beziehungsweise im und durch Handeln erst erzeugt wird, da „der (soziale) Raum ein (soziales) Produkt ist“ (Dünne und Günzel 330; Hervorhebung im Original). Er ebnet damit den Weg für einen wissenschaftlichen Diskurs, der im Gegensatz zur Postmoderne nicht die Zeit-, sondern die Raumdimension valorisiert. Doris Bachmann-Medick führt diese Entwicklung historisch auf das Ende des Kalten Krieges und der binären Weltordnung von Ost und West zurück, welche eine politische und ökonomische Neuordnung geschaffen habe, die sich auch sozial und kulturell niedergeschlagen habe. Durch die Veränderung zu einer globalen Welt sei die Wiederkehr der Raumfrage vorprogrammiert:

Die Einsicht, dass die globalen Entwicklungen nicht mehr von individuellen nationalstaatlichen Akteuren gesteuert werden können, sondern dass sie von einer Konstellation wechselseitiger Abhängigkeiten und Beziehungsnetzwerke geprägt sind, Vernetzung als Eigenschaft von Globalisierung, macht die Raumperspektive unvermeidlich. (287) 
In diese Zeit fällt die Herausbildung postkolonialer Theorien, welche gegen die Hegemonie imperialer Räume den Moment des Konfliktes akzentuierten, um Raum als Handlungsraum stark zu machen. In diesem Handlungsraum steckt ein subversives politisches Potenzial, Veränderung herbeizuführen und koloniale Machtverhältnisse umzukehren.

\subsubsection{Entterritorialisierung}

In seiner 1978 erschienenen Monographie Orientalism kritisiert der Literaturwissenschaftler Edward Said jenes koloniale Machtverhältnis und entlarvt den „Orient“ als Konstrukt und Imagination des Westens. Dabei macht er zunächst den Moment von Differenz stark, der die Abgrenzung gegenüber anderen, die Bezeichnung eines „wir“ gegenüber „denen“ räumlich manifestiere: „This universal practice of designating in one's mind a familiar space which is ,ours ' and an unfamiliar space beyond ,ours' which is ,theirs' is a way of making geographical distinctions“ (54). Die Metapher des Raumes sowie der Raum selber werden in seinen Ausführungen zu einem Vehikel für Identitätskonstruktionen.

Raum ist hierbei untrennbar mit historischen und vor allem politischen Strategien verbunden - einer Geopolitik, die auf Machtverhältnisse abzielt und sich in Repräsentationspraktiken niederschlägt. Als Beispiele für frühe Repräsentationen bedient sich Said der Literatur und nennt Autoren wie Victor Hugo, Johann Wolfgang Goethe, Gustave Flaubert und Francis Scott Fitzgerald, bevor er auf Die Perser von Aischylos und Die Bacchien von Euripides näher eingeht. Klare Zuschreibungen zwischen den Griech_innen, also den Europäer_innen, und den „barbarischen Völkern“, also den Perser_innen, stellen ein rationales, überlegenes Europa einem rohen und dummen Orient gegenüber. Er nennt des Weiteren die Bibel sowie die frühe Geschichtsschreibung als Beispiele für Repräsentatio- 
nen des sogenannten Orients, geht aber wenig auf visuelle Darstellungsmodi ein. Repräsentation an sich ist in Saids Ausführungen immer performativ zu verstehen: „The Orient is the stage on which the whole East is confined“ (63). Als Bühne bekommt der sogenannte Orient klare räumliche Grenzen und Europa die Rolle des Puppenspielers und Drahtziehers. Imperialistische, eurozentrische Diskurse hätten dadurch den sogenannten Orient als das „Andere“ von Europa charakterisiert und so eine europäische Imagination dessen geschaffen. Diese Repräsentationen ${ }^{25}$ würden den geographischen Ort entlang von Stereotypen und Binaritäten beschreiben und so zu einer Imagination beitragen, die dem realen Ort, ob seiner kulturellen und sozialen Vielfalt, in keiner Weise gerecht werde. Geographische Distanz bedeutet in diesem Fall auch ideelle Distanz: „For there is no doubt that imaginative geography and history help the mind to intensify its own sense of itself by dramatizing the distance and difference between what is close to it and what is far" (Said 55). Die im kognitiv-imaginären Bereich entstehende Grenzziehung zwischen dem Eigenen und dem „Anderen“ wirkt dabei zurück in die Konstruktion geographischer Räume. Der jeweils eigene Standort und die damit assoziierte soziokulturelle Identität werden in Relation zum „Anderen“ gesetzt und dabei verhandelt. Heutzutage ließe sich, was bereits im neunzehnten Jahrhundert für illustrierte Zeitschriften galt, eine solche imaginative geography anhand von medial übertragenen Nachrichten und Reportagen festmachen: „Medienberichte dieser Art bilden die Basis einer imaginären Geographie, die voll ist mit Vorstellungen und Bildern von verschiedenen Räumen und den Menschen, die dort leben“" (Hipfl 16). ${ }^{26}$

Saids Interesse an den kolonialen und imperialen Visualisierungen beschränkt sich auf deren metaphorische Natur als konstitutives Element in Bezug auf Identität. Saids imaginative geography ist ein Konzept, in dem Repräsentationen von Raum immer mit Machtverhältnissen korrelieren, wodurch sie Identi- 
tätskonstruktionen sichtbar machen. Dies meint nicht nur die Produktion von Raum durch geschichtliche Ereignisse, sondern lokalisiert den Akt der Repräsentation dieser Ereignisse räumlich und performativ. Raum als sozialer Raum der Erfahrung, Handlung und Produktion wird mit der symbolischen und metaphorischen Ebene der Raumrepräsentation gekoppelt. Dies ebnet den Weg für den Raumbegriff als Analysekategorie. Vielschichtige und widersprüchliche gesellschaftliche Prozesse, wie sie insbesondere auch innerhalb von Diaspora zu beobachten sind, die verstärkt Simultaneitäten, Überlappungen, Verflechtungen, Verschränkungen, Überschreibungen und Beziehungsgeflechte akzentuieren, können so konzeptuell gefasst werden. Damit ist das Konzept für den Diasporabegriff ein erster relevanter Anknüpfungspunkt.

Arjun Appadurai entwickelte im Hinblick auf Beziehungsgeflechte ein eingängiges Modell, jenes der global scapes. In seinem 1996 veröffentlichten Buch Modernity at Large beschäftigt er sich mit der Frage nach dem Verhältnis zwischen Wissenschaft, Kultur und Repräsentation in einer zunehmend globalisierten Welt. Sein Ansatz geht vom Raum als Fläche oder Sphäre aus. Zentral dabei sind die mannigfaltigen Vernetzungen, die sich aus den Strukturen der Globalisierung ergeben. Umso wichtiger sei es, den „link between space, stability, and cultural reproduction“ (Modernity at Large 49) zu untersuchen. Als einen wichtigen Motor kultureller Dynamiken nennt Appadurai deterritorialization, die Austauschmöglichkeiten über Nationalgrenzen hinweg ermögliche. Das Konzept der De- beziehungsweise Re-Territorialisierung stammt von Gilles Deleuzes und Félix Guattaris L'Anti-Oedipe, die dieses im Zusammenhang mit der Sprachphilosophie gleichsam als Moment der Entfernung von der Sprache verorteten. Das Konzept fand durch Theoretiker wie Akhil Gupta und James Ferguson (,Beyond ,Culture“") Eingang in die Kultur- und Sozialanthropologie, bevor Arjun Ap- 
padurai es für seine global scapes produktiv machte. Transnationale Bewegungen oder auch cultural flows sind kennzeichnend für die sich weltweit intensivierenden Beziehungen. Der Idee der scapes und flows wohnt der Gedanke inne, dass Kultur und Raum nicht mehr in eins fallen, in dem Sinne, dass jede Kultur einen bestimmten Raum beherrscht und jeder Raum notwendig eine bestimmte Kultur hervorbringt. Sie werden damit als sich gegenseitig stabilisierende Einheiten aufgebrochen.

Appadurai unterscheidet als Folge der flows fünf solcher scapes: Menschen, Ideen-, Finanz-, Technik- und Medienströme, die auf der Welt orts- und zeitungebunden zirkulieren. Ethnoscapes beschreibt Strömungen verschiedener Ethnien über verschiedene Räume hinweg und beinhaltet verschiedene mobile Gruppen wie Migrant_innen, Gastarbeiter_innen, Exilant_innen, Flüchtlinge, Touristen und Menschen in diversen auch diasporischen Formationen:

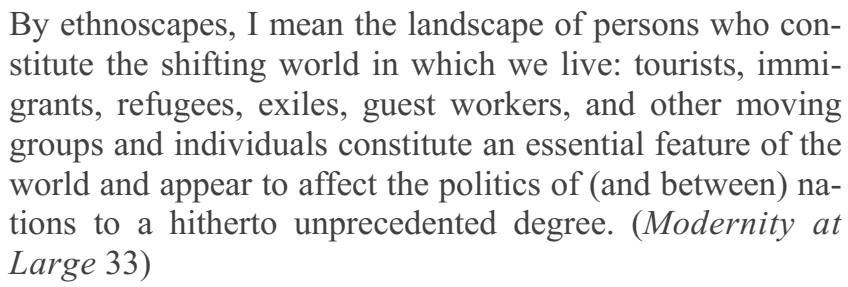

Ideoscapes meint die grenzüberschreitende Verbreitung von Vorstellungen und Ideen, ähnlich Saids Begriff der travelling concepts, wie etwa Freiheit, Sozialwesen, Recht, Souveränität oder Demokratie: „Ideoscapes are composed of elements of the Enlightment worldview, which consists of a chain of ideas, terms, and images, including freedom, welfare, rights, sovereignity, representation, and the masterterm democracy“ (36). Finanscapes meint grenzüberschreitende Bewegungen von Kapital und komplexen Finanzströmen über internationale Drehscheiben wie Devisenmärkte und nationale Börsen: 
„Currency markets, national stock exchanges, and commodity speculations move megamonies through national turnstiles at blinding speed, with vast, absolute implications for small differences in percentage points and time units“ (34-35).

Technoscapes beschreibt wiederum grenzüberschreitende Bewegungen von Technologien und technischem Wissen: „The global configuration, also ever fluid, of technology and the fact that technology, both high and low, both mechanical and informational, now moves at high speeds across various kinds of previously impervious boundaries“ (35). Mediascapes meint mediale Austauschprozesse und grenzüberschreitende Verflechtungen elektronischer Medien:

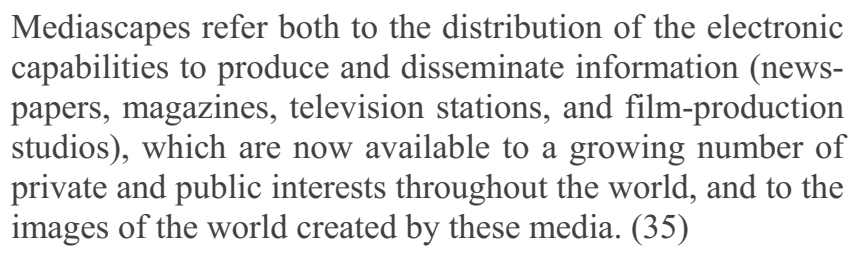

Es sind diese Verflechtungen, Vernetzungen und Austauschprozesse, die im Konzept der global scapes den physisch-territorial-nationalen Raum überschreiten, um ihn durch neue, sich immer wieder konfigurierende Räume zu überschreiben. Diese Räume sind durch die Aushandlung von Identität geprägt, vielgestaltige Erfahrungsräume die über die Welt zerstreute Menschen zusammenführen. Räume entstehen in Appadurais Modell aus einem stetigen Prozess verschiedener zeit- und raumübergreifender Bewegungen, wodurch folgerichtig auch die Diasporakultur in und durch Bewegung produziert wird.

Der ebenso programmatische wie für die postkolonialen Raumkonzepte des spatial turn bezeichnende Titel von Homi K. Bhabhas 1994 veröffentlichtem Werk The Location of Culture interessiert sich ähnlich wie Edward Said und Arjun Appadurai für die Frage nach der Verortung von Kultur. Homi K. Bhabha 
schlägt darin das Konzept des third space vor, in welchem Kultur nicht durch Raum definiert und Raum nicht durch Kultur produziert wird. Die Begegnung und Interaktion verschiedener Kulturen selbst schafft den Raum, ein Prozess, der nicht auf einzelne Faktoren, Agenten oder Orte zurückgeführt werden kann: „The historical difference of the present is articulated in the emergence of a third space of representation“ (316). Der third space ist ein Aushandlungs- und Möglichkeitsraum, in welchem Begegnungen, Konfrontationen und Widersprüchlichkeiten stattfinden können, und konzipiert damit einen Raum, in welchem Kultur nicht monolithisch, sondern polyvalent erfasst wird:

It is that Third Space, though unrepresentable in itself, which constitutes the discursive conditions of enunciation that ensure that the meaning and symbols of culture have no primordial unity or fixity; that even the same signs can be appropriated, translated, rehistoricized and read anew. (55)

Einerseits wird in diesem Konzept die Loslösung von Raum als physischterritorial-nationale Entität fortgeführt, andererseits jedoch auch nicht als reine Metapher oder Symbolik verstanden. Vielmehr fällt hierbei beides in einen „realand-imagined place“ (Soja 6) zusammen: „The non-synchronous temporality of global and national cultures opens up a cultural space - a third space - where the negotiation of incommensurable differences creates a tension peculiar to borderline existences“ (Bhabha 312). Mit der Raummetapher des third space macht Homi K. Bhabha die Komplexitäten, Vielschichtigkeiten und Verflechtungen von Kultur sichtbar und eröffnet eine konzeptuelle wie analytische Kategorie, die auch für den Begriff der Diaspora produktiv gemacht werden kann. Diese Spannung beinhaltet, im Hinblick auf das spätere Kapitel „Zwischenräume“, auch ein 
kreatives wie subversives Potenzial für filmische Transformationsprozesse und Enunziationen.

Alle drei Ansätze gehen von einem relationalen Raumbegriff aus. Edward Said, indem er Raum und Imagination koppelt und damit die Konstruiertheit, gar Beliebigkeit, von kulturgeographischen Entitäten, wie auch Diaspora eine ist, aufzeigt. Arjun Appadurai hingegen hebt das Moment der Austauschbewegung in seinem Konzept hervor, was zweifelsohne ein konstitutiver Bestandteil von Diaspora ist. Homi K. Bhabha spricht sich nicht nur für eine Mehrdirektionalität von Austauschbewegungen aus, sondern für die Kontaktzonen, die im Moment der Vermischung und Vermengung selbst entstehen, womit sich seine Herangehensweise für die nachstehenden filmanalytischen Auseinandersetzungen besonders eignet. Der Verflüssigung, Hybridisierung und Undarstellbarkeit kultureller Gefüge stehen jedoch auch Gegenreaktionen in Form von Rückbesinnung auf „traditionelle“ Werte in einer Wiederentdeckung des Lokalen sowie existierender Staatsgrenzen, die mitunter harte Grenzregime mit sich bringen (EUAußengrenze, USA-Mexiko, et cetera), gegenüber. Auch sie sind Teil des spatial turn. Wiederkehrende Topoi im Zusammenhang mit Diaspora sind dabei jene des Hauses und des homeland.

\subsubsection{Abkehr von der Rückkehr}

Die einschlägige Diasporaforschung postuliert ,an orientation towards the homeland as an essential feature of diasporic identity; [...]“ (Tölölyan 9). Zum einen geht es dabei um geographisch-reale Räume der Rückkehr, denn mit Ausnahme der Diaspora der Roma und Sinti, so Khachig Tölölyan, ,,all other dispersions are seen as having a homeland and being oriented towards it“ (9). Zum anderen geht 
es dabei um symbolische Räume der Rückkehr, wie Edward Said in Anlehnung an den Philosophen Gaston Bachelard und sein Werk Poetik des Raums beschreibt:

The objective space of a house - its corners, corridors, cellar, rooms - is far less important than what poetically it is endowed with, which is usually a quality with an imaginative or figurative value we can name and feel; thus a house may be haunted or homelike, or prisonlike or magical. So space acquires emotional and even rational sense by a kind of poetic process, whereby the vacant or anonymous reaches of distance are converted into meaning for us here. (55)

Die Historikerin Patricia Seed zieht in ihrem Artikel „The Key to the House“ das Beispiel marokkanischer und tunesischer Häuser heran, in denen große Schlüssel über die Eingangstür gehängt werden, um symbolisch an den Verlust ihrer Häuser auf der iberischen Halbinsel zu erinnern, welche sie vor über fünfhundert Jahren verlassen mussten (85-94). In der Diaspora, so Hamid Naficy, fallen das physische und das symbolische „Zuhause“ zusammen: „One’s relation to „home“ and ,homeland' is based as much on actual material access as on the symbolic imaginings and national longings that produce and reproduce them“ („Framing Exile“ 5). Stéphane Dufoix sieht das in seiner Definition von Diaspora in einer ähnlichen Stoßrichtung: „Taken in all its usages, ,diaspora“ is like the god Janus: It looks both to the past and to the future. It allows dispersion to be thought of either as a state of incompleteness or a state of completeness. The issue of origin arises in both cases“" (34).

Khachig Tölölyan erkennt die Diskurse um home und homeland in und für die Diaspora Studies zwar an, weist jedoch - ähnlich wie James Clifford in seiner Kritik an William Safran - darauf hin, dass der Rückbezug und Rückkehrgedanke keineswegs als Automatismus für in der Diaspora lebende Menschen gesehen werden sollte und erst recht nicht für eine Definition von Diaspora herhal- 
ten kann. Er bezieht sich dabei auf Interviews, die er mit jungen Studierenden geführt hat, welche ihre Zugehörigkeit zu einer Diaspora nicht über ein Herkunftsland definieren, dieses mitunter sogar verbergen, herunterspielen oder einfach nicht als erwähnenswert erachten (Tölölyan 9-11). Michel Laguerres Aussage ,the diaspora may be constructed as a community, a state, or a province of the homeland“ (641) ist für ihn dabei symptomatisch für das Problem, Diaspora nicht als eigenständigen Raum, sondern lediglich als „tentacles of the nation“ (648) zu konzipieren.

Khachig Tölöyans Argumentationslinie folgend, möchte ich an dieser Stelle mein Verständnis von Diaspora als eigenständigen Raum abseits eines realen oder symbolischen homeland als flexible und offene Region konzipieren. Ein offener und beweglicher Begriff der „Region“, der bis zu einem gewissen Grad immer essentialistisch aufgeladen bleibt, ist hierbei für ein erweitertes Verständnis von Diaspora entscheidend. Die Forschungsansätze der Area Studies beziehungsweise Regionalstudien bilden hierzu den theoretischen Rahmen.

Ursprünglich im Kalten Krieg entstanden, sollten Area Studies den Vereinigten Staaten Informationen und Wissen über andere Weltregionen, vor allem jenen des damaligen Ostblocks, verschaffen. Die neue Disziplin schlug sich bald auch auf andere Weltregionen wie Lateinamerika, Afrika und der MENA-Region (Middle East and North Africa) nieder. Dass bereits im sogenannten Orientalismus Wissen über die MENA-Region zu politischen Zwecken genutzt wurde, zeigte bereits Edward Saids epochales Werk Orientalism auf. Im Kapitel „Knowing the Oriental“ beschreibt er die klassische Orientforschung als zweckgebundene Wissenschaft, die ihre Tätigkeit hauptsächlich zur Legitimierung kolonialer Machtstrukturen ausübt. Dreißig Jahre später spricht der Historiker und Philosoph Hamid Dabashi in seiner gleichnamigen Monographie von „Post- 
Orientalismus“ und erklärt die disziplinäre Veränderung von Orientalismus zu Area Studies wie folgt: „Orientalism was strategically oriented, Area Studies was far more policy-driven“ (Post-Orientalism 104-05). Nach dem Fall des Eisernen Vorhanges und dem Ende der Einteilung der Welt in West-Ost-Blöcke sei der Nutzen der Area Studies nicht minder relevant geworden, sondern würde weiterhin für die imperiale Vormachtstellung der Vereinigten Staaten brauchbar gemacht werden: „The gradual mutation of old-fashioned Orientalists into Area Studies specialists is now further transmuting into a class of barefaced propagandists in close collaboration with think tank strategist" (106). Demzufolge wären Area Studies keine unabhängigen Forschungen, sondern immer durch Politik, Think-Tanks et cetera beeinflusst. Hamid Dabashi schlägt in diesem Zusammenhang den Begriff der epistemic endosmosis als neueste Entwicklung der Wissensproduktion über die MENA-Region vor, ,,a phase when such useful knowledge is no longer predicated on a particular manner of subject-formation, for it is predicated on no particular paradigmatic or epistemic formation“ (xvii). Dieses nützliche Wissen sei nicht mehr einer oder mehreren klassischen Wissensproduktionsstätten wie Universitäten oder Forschungsinstituten zuzuschreiben, sondern würde eine dissonante Verbreiterung in diversen Foren und Formen finden: „epistemic endosmosis, namely a phase in the post-Orientalist period when such knowledge [...] is in fact widely disseminated in varied forms of private and public forums, and as such resisting categorization and operating on a cacophonous modulation“ (Post-Orientalism 222; Hervorhebung im Original). Hamid Dabashi stellt in diesem Zusammenhang die Frage nach Akteur_innen und Disziplinen und konstatiert dabei eine Leerstelle, die eine Rückführung sowohl auf das Eine als auch auf das Andere nicht mehr ermöglicht: „Today in fact we are witnessing a mode of knowledge that is devoid of agential subjectness" (213). Dies begründet er vor allem durch die Nähe und Vereinbarkeit von Wissenspro- 
duktion mit imperialen Imaginationen und Konstruktionen: „The origin and function of this mode of knowledge are compatible with the imperial imaginary they serve“ (213).

Solch eine Verschiebung der Wissensproduktion vom Zentrum in die Peripherie setzt die Politikwissenschaftlerin Claudia Derichs wiederum mit einer Verschiebung - einem „new areas studies current“ (33) - von einem abgegrenzten zu einem offenen Begriff von Region gleich: „Shifting the view from the centers to the peripheries of knowledge production, and from conventionally demarcated regions to non-demarcated regions“ (33). In diesem Sinne ist die Kategorie der Region selbst nicht hermetisch ab- oder in sich geschlossen. Was unter den Begriff Region fällt, wie dieser definiert wird und vor allem was er bezeichnet, unterliegt historischen Wandlungsprozessen. Sie bezieht sich dabei auf Arjun Appadurais Ansatz, Geschichtlichkeit würde Räume erzeugen und nicht umgekehrt: „We need to recognize that histories produce geographies and not vice versa. [...] It is historical agents, institutions, actors, powers that make the geography“ („Histories“ 9). Verschiedene Weltregionen und somit Region selbst können, auch laut den Sozial- und Regionalwissenschaftlerinnen AnnaKatharina Hornidge und Katja Mielke, daher nicht per se als singuläre oder hermetische Einheiten definiert werden, hingegen müssen sie stärker als dynamische Kategorien gefasst werden: „[The] division of the world into territorially fixed ,areas' as ,containers', defined by certain character traits to be found on the ,inside', but instead demands conceptualizations of ,area ' that take these dynamisms into account“"(14). Diese Entwicklung in den Area Studies selbst und dem damit einhergehenden Wandel von einem unflexiblen hin zu einem elastischen Verständnis von Region beschreiben auch die Kulturwissenschaftlerin Ines Braune und der Islamwissenschaftler Achim Rohde: 
[Area studies] moved away from container concepts of regions as seemingly congruent and separate entities and their concomitant epistemological othering in scholarship, towards emphasizing comparative aspects and global entanglements in terms of migration, knowledge flows and economic ties. (6)

Sie heben deshalb ineinandergreifende Strukturen hervor, die Region nicht als einen Raum, sondern als eine Gesamtheit verschiedener Räume begreifen: „We are dealing today with a socially constructed ensemble of interdependent social, cultural and economic spaces across and beyond physically or politically defined areas" (7). Dabei nehmen sie einen dezidiert kulturwissenschaftlichen Standpunkt ein, der Räume als verflochten und dabei durchaus auch widersprüchlich und gegensätzlich konzipiert. Dem zugrunde liegt der von Anna-Katharina Hornidge geprägte Begriff der „,post-Area Studies““ (17), der von der Annahme ausgeht, dass statische politische, soziokulturelle, ethnische und religiöse Grenzen durch ein erhöhtes Ausmaß an Mobilität zunehmend infrage gestellt werden: „The mobility of people, goods, ideas, and viruses inherently questions political borders and socio-cultural, ethnicity- and religion-based boundaries“" (Hornidge und Mielke 13). Herausgestrichen wird dabei auch hier das Moment des dynamischen und beweglichen Raumes: „Some of the geographically fixed categories that our world operates in are increasingly characterised by degrees of dynamism that transcend territorial fixity“ (14).

Wenn mensch den relationalen Raumbegriff, wie er aus dem spatial turn hervorgegangen ist, zum Ausgang nimmt, ist meines Erachtens Diaspora als Region zu konzipieren, die weder als geographische noch als symbolische Entität $\mathrm{zu}$ fassen ist und damit eine eindimensionale Betrachtungsweise ausschließt. Mit dem von Avtar Brah, ihres Zeichens Soziologin, geprägten Begriff des diaspora space möchte ich für Diaspora als multidimensionales Phänomen argumentieren, 
welches durch einen flexiblen Begriff der Region als eigenständiger Raum konzipierbar wird. In ihrem Artikel „Diaspora, Border and Transnational Identities“ fasst sie 2003 Diaspora als Referenzrahmen zur Analyse gesellschaftlicher Phänomene: „An interpretive frame referencing the economic, political, and cultural dimensions of these contemporary forms of migrancy“ (620). In Anlehnung an Diskurse rund um Minoritäten/Majoritäten und die Frage nach der Verhandlung von Grenzen/Grenzziehungen konzipiert sie Diaspora als einen gelebten Raum der gemeinsamen Erfahrung aller direkt und indirekt Beteiligten:

\section{Diaspora space as a conceptual category is ,inhabited" not only by those who have migrated and their descendants but equally by those who are constructed and represented as indigenous. In other words, the concept of diaspora space (as opposed to that of diaspora) includes the entanglement of genealogies of dispersion with those of ,staying put'. (Cartographies of Diaspora 181)}

Im Zusammenhang mit nativistischen Diskursen löst sie die Trennlinien zwischen „Ursprünglichem“ und „Diasporischem“ auf: „The native is as much a diasporian as the diasporian is the native“ („Diaspora, Border and Transnational Identities“ 632). Brah unterscheidet zwischen „diaspora“ und „diaspora space“, indem auch sie die Kategorie des homeland mit dem damit verbundenen Rückkehrgedanken ablehnt: „The concept of diaspora offers a critique of discourses of field origins, while taking account of a homing desire which is not the same thing as desire for a homeland“ (614). Sie schlägt hingegen das Konzept des homing vor, welches den Wunsch oder die Sehnsucht nach einem „Zuhause“ oder „Sich-zu-Hause-Fühlen“ meint. Trotz dieses Wunsches würden nicht alle in einer Diaspora lebenden Menschen die Rückkehr zu einem real-territorialnationalen Herkunftsland anstreben, denn dieser historischen und politischen Änderungen unterworfene Raum entspricht zumeist nicht der Erinnerung und 
dem Wunsch der in der Diaspora Lebenden. Die Soziologinnen Nina Glick Schiller, Tsypylma Darieva und Sandra Gruner-Domic sehen ihrerseits für das Aufrechterhalten der Beziehung zwischen Herkunftsland und Diaspora dabei auch keine zwingende Notwendigkeit:

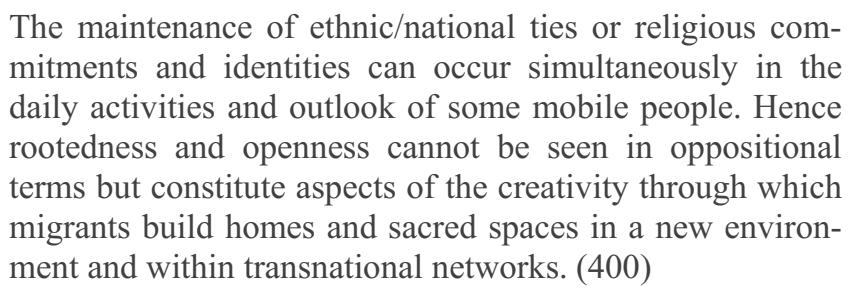

Selbst wenn es also keinen physischen Ort der Rückkehr mehr gibt, so bewirkt das Zusammenspiel von Verwurzelungstendenzen auf der einen und Weltoffenheit auf der anderen Seite doch - wie auch im Beispiel von Patricia Seed und den Schlüsseln in den marokkanischen und tunesischen Häusern - das Bestehen des Wunsches oder der Sehnsucht nach einem „zu Hause“. Dieser Wunsch ist es, den Avtar Brah homing nennt und als konstitutives Element der Diaspora beschreibt, da er nicht nur in der Projektion auf einen symbolischen Sehnsuchtsort hindeutet, sondern auch auf eine Lebensart innerhalb der Diaspora selber. Avtar Brahs Konzept des diaspora space bietet so die Möglichkeit, die Analyse solcher Phänomene, die durch Migration und kulturellen Austausch gekennzeichnet sind, nicht außer-, sondern innerhalb einer Gesellschaft durchzuführen. Auch Nina Glick Schiller, Tsypylma Darieva und Sandra Gruner-Domic bekräftigen gegenüber einem statischen Begriff von „zu Hause“ die Perspektivierung von Dynamiken und Wechselwirkungen kultureller Beziehungsgeflechte: „Beyond the celebration of difference and multiculturalism to an analysis of when and where people use their diverse cultural or religious backgrounds to build relationships and identities of openness" (401). 
Die hier skizzierten sozial- und regionalwissenschaftlichen Ansätze schließen an den relationalen Raumbegriff von Edward Said, Arjun Appadurai und Homi K. Bhabha an und dienen in ihrer Summe der Erweiterung des Begriffes der Diaspora, die sich aktuell nicht mehr allein durch die Binarität homeland/hostland definieren lässt. Meine Definition charakterisiert demnach Diaspora nicht mehr durch Rückkehrwunsch, sondern durch Offenheit. Diaspora als fixierter Raum, der immer nur in Abgrenzung zu einem realen oder symbolischen homeland gesetzt wird, weicht einem flexiblen und offenen Begriff der Diaspora als Region, der verstärkt kulturelle Vernetzungen, Verflechtungen und Austauschprozesse eindenkt. ${ }^{27}$ Das Ineinanderwirken von Strukturen und individuellen Entscheidungen kann somit abseits kultur-essentialistischer Zuschreibungen zusammen betrachtet werden, wie im Folgenden dargelegt und im Hinblick auf spätere Kapitel auch für eine filmwissenschaftliche Betrachtungsweise produktiv gemacht werden soll.

\subsection{Diaspora und Kultur}

Im Zusammenhang mit Diaspora ist Kultur als dynamisch, fragmentiert und im ständigen Wandel befindlich zu begreifen. Sie ist eng an soziale Praktiken und Gemeinschaftsleben gebunden, aber auch an die Institutionalisierung einer normativen Ordnung sowie den Widerstand gegen diese. Der sogenannte cultural turn meint einen Paradigmenwechsel in den Sozial- und Kulturwissenschaften, der gesellschaftliche Phänomene nicht mehr entlang von statischen Kategorien, sondern vielmehr entlang aufgeweichter Einteilungen beschreibt (BachmannMedick 7-57). Kultur umschreibt demnach ein Terrain des politischen und ideo- 
logischen Kampfes, in dem gesellschaftliche Konventionen, Normen, und Werte ständig bestritten und (wieder-)ausgehandelt werden.

Diese veränderte und erweiterte Bedeutung von Kultur entstand im Kontext der im angelsächsischen Wissenschaftsdiskurs aufkommenden Cultural Studies. Als ersten wegweisenden Text, der aus der Tradition der englischen Literaturwissenschaft entstanden ist, nennen die Kulturwissenschaftlerin Christina Lutter und der Kulturhistoriker Markus Reisenleitner in ihrer Einführung den 1958 veröffentlichten Text The Uses of Literacy des Kultursoziologen Richard Hoggart (23-25). In diesem literaturwissenschaftlichen Ansatz wird Kultur zum ersten Mal nicht nur im Sinne von Hochkultur, sondern auch im Sinne von Populärkultur verstanden. Das Alltagsleben der Arbeiterklasse rückt in den Fokus, und Erfahrung wird dabei zur zentralen wissenschaftlichen Analysekategorie (Hoggart). Der Kulturtheoretiker Raymond Williams verfolgt einen ganz ähnlichen Ansatz von Kultur als gelebter Erfahrung, für ihn beschreibt Kultur: „,[A] whole way of life, $[\ldots]$ as a mode of interpreting all our common experiences“ („Culture Is Ordinary“ 3). In seinem 1953 erschienenen Artikel „The Idea of Culture“ zeichnet er die Entwicklung des Kulturbegriffes etymologisch und historisch nach. Beide bis dahin gültigen Definitionen von Kultur, als ,,a state of mind“ und als „leisure-time activity“ (241), genügen seiner Meinung nach den gesellschaftlichen Anforderungen und Veränderungen des zwanzigsten Jahrhunderts nicht: Weder kann Kultur als reine Hochkultur noch als purer Zeitvertreib definiert werden, vielmehr gilt: „The idea of culture is a focusing of a number of particular responses to change“ (245). Für Williams sind es jedoch nicht nur einzelne Erfahrungen, sondern die Gesamtheit der Lebenswelt, welche Kultur als Antwort auf Veränderungen ausmacht: „The idea of culture is not to be considered as a process of independent evolution; it is shaped and at times directed by the total environment to which it is one kind of response“ (245). Kultur ist somit 
nicht nur die Summe künstlerischer Ausprägungen, die der Festigung nationaler Bindungen dient, sondern umfasst eine Lebensart und Gemeinschaftserfahrung. Durch dieses wissenschaftliche Interesse für Alltagserfahrungen finden auch populärkulturelle Formen wie Fernsehen, Radio und Film Eingang in die Kulturdebatte. In The Making of the English Working Class führte der Historiker Edward P. Thompson in diese Debatte das Element des Konfliktes ein und interessierte sich für die Momente der Störungen und Diskontinuitäten von antagonistischen Lebenserfahrungen. Bezugnehmend auf den Begriff der „Hegemonie“ des Philosophen Antonio Gramsci liegt Thompsons Ziel darin, Klassenunterschiede weniger als historisch statisch als vielmehr kulturell motiviert zu begreifen. Alle drei zitierten Autoren konzeptualisierten Kultur als soziale Praxis und ebneten somit den Weg für eine breite kritische Auseinandersetzung, die sich auch institutionell niederschlagen konnte.

\subsubsection{Anti-Essentialismus}

Das 1964 gegründete Birmingham Center for Contemporary Cultural Studies gab den Cultural Studies ihren ersten und wichtigsten institutionellen Rahmen. Von Beginn an interdisziplinär ausgerichtet, sollte es der Analyse kultureller Formen, Praktiken und Institutionen dienen. ${ }^{28}$ Unter der sukzessiven Führung von Richard Hoggart, Stuart Hall und Richard Johnson entwickelte sich das Zentrum zu einem der tonangebenden Institute in der Erforschung von massenund populärkulturellen Phänomenen. Dieses Credo schrieben sich auch die amerikanischen Cultural Studies auf die Fahnen, die jedoch im Gegensatz zu den britischen Cultural Studies weniger an einer bestimmten Institution auszumachen sind, als vielmehr eine Vielzahl von Wissenschaftler_innen und Disziplinen beinhalten. Beiden Schulen gemein ist, dass sie über den wissenschaftlichen 
Anspruch von Theoriebildung hinaus die Erforschung von Kultur auch als politischen Auftrag sahen. In Analogie zu postkolonialen Theoriebildungen ging es ihnen um das Aufzeigen von Machtstrukturen und den Möglichkeiten gesellschaftlicher Veränderungen. Damit sollte die akademische Arbeit in die Gesellschaft selbst rückwirken.

Nicht nur als Zentrumsdirektor des Birmingham Center for Contemporary Cultural Studies, sondern vor allem auch mit einer Reihe von Schriften beeinflusste der Soziologe Stuart Hall maßgeblich den angelsächsischen Diskurs der Cultural Studies. In Anlehnung an Raymond Williams und Edward P. Thompson folgt auch er in seinem Aufsatz „Cultural Studies: Two Paradigms“ der Unterscheidung zwischen Hoch- und Populärkultur:

It [culture] no longer consists of the sum of the ,best that has been thought and said', regarded as the summits of an achieved civilization that ideal of perfection to which, in earlier usage, all aspired. Even, art $^{6}$ - assigned in privileged position, as touchstone of the highest values of only one, special, form of a general social process: civilization - is now redefined as only one, special, form of a general process: the giving and taking of meanings, and the slow development of ,common' meanings - a common culture: ,culture', in this special sense, ,is ordinary'. (59)

Stuart Hall geht jedoch über die bloße Unterscheidung zwischen Hoch- und Populärkultur hinaus und macht den Aspekt der Sinnstiftung als gemeinschaftlichen Akt, der zu einer gemeinsamen Kultur führe, stark. Kultur sei in diesem Sinne als etwas „Gewöhnliches“, Alltägliches zu sehen. Kultur als eine einzige soziale Praxis zu begreifen, lehnt er jedoch ab: „Culture“ is not a practice; nor is it simply the descriptive sum of the ,mores and folkways' of societies - as it tended to become in certain kinds of anthropology. It is threaded through all social practices, and is the sum of their inter-relationship“ (60). Vielmehr müsse 
Kultur als Teil aller sozialen Praktiken und diese wiederum als gemeinschaftliche Form menschlicher Aktivität allgemein gesehen werden.

In seinem Text „Cultural Identity and Diaspora“ beschäftigt er sich eingehender mit dem Kulturbegriff in Zusammenhang mit Diaspora. In diesem setzt er sich über essentialistische Zuschreibungen von kultureller Identität hinweg. Im Lichte des Postkolonialismus konzipiert er eine Definition von kultureller Identität, die sich vor allem durch Prozesshaftigkeit auszeichnet. Kulturelle Identität als

one, shared culture, a sort of collective , one true self ${ }^{6}$, hiding inside the many other, more superficial or artificially imposed ,selves', which people with a shared history and ancestry hold in common [...] with stable, unchanging and continuous frames of reference and meaning. (223)

würde zwar eine Möglichkeit der Definition sein, den Veränderungen eines neuen diasporischen Selbstbewusstseins (als Beispiel nennt er die karibische Diaspora) jedoch nicht gerecht werden. Dieses Bewusstsein würde sich nicht mehr entlang eines wie auch immer gearteten Essentialismus ausdrücken, sondern stärker entlang von Differenzen, Brüchen und Diskontinuitäten:

There are also critical points of deep and significant difference which constitute, what we really are'; or rather - since history has intervened -, what we have become'. We cannot speak for very long, with any exactness, about, one experience, one identity', without acknowledging its other side - the ruptures and discontinuities. (225)

Das Moment der Differenz macht auch Homi K. Bhabha stark und unterscheidet in einem Interview mit dem Kulturwissenschaftler Johnathan Rutherford zwischen cultural difference und cultural diversity. Cultural diversity meint eine multikulturell orientierte Politik, kulturelle Vielfalt positiv zu beset- 
zen. Die dadurch entstehenden Zuschreibungsmechanismen der verschiedenen Gruppen einer Gesellschaft würden keine Durchlässigkeit mehr erlauben, sondern Ethnien als abgeschlossene Entitäten festschreiben. Cultural difference wiederum setzt Unterschiede voraus, die nicht statisch sind, sondern einen prozessualen Charakter haben, der kulturelle Interaktionen ermöglicht:

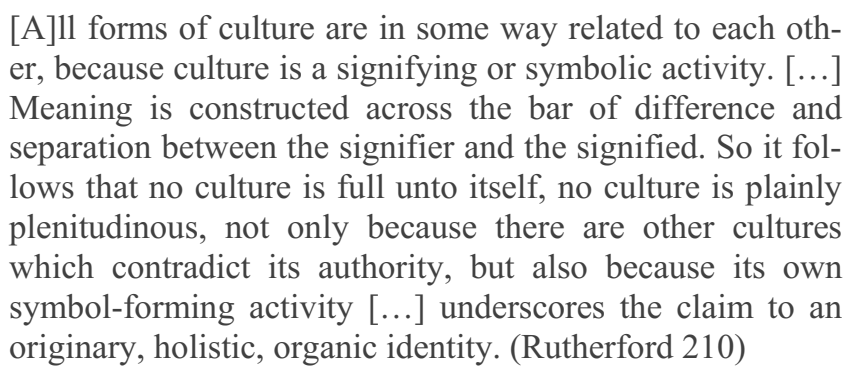

Ausgangspunkt seiner Überlegungen ist die Diagnose, dass Konzepte homogener Nationalkulturen, ungebrochener Traditionen und quasi-organischer ethnischer Kollektive zunehmend an Plausibilität verlören. Neben geschichts- und geopolitischen Postulaten folgt aus der Einsicht in die Notwendigkeit der Revision überkommener Konzepte von Kollektivität und kultureller Identität für Bhabha konzeptuell, Kulturen niemals als einheitlich und damit nicht als gegeben, sondern vielmehr als Felder der Aushandlung von Differenz zu verstehen.

Beide Ansätze sind wichtige Wegweiser, um auch Diaspora und Diasporakultur als nicht essentialistisch zu begreifen. Diaspora ist nichts Abgeschlossenes, in sich Kohärentes, was einfach entlang kultureller Diversität kategorisierbar wäre, sondern prozesshaft, komplex und vielschichtig. Es ist der Ausdehnung des Kulturbegriffes im Zuge der Cultural Studies zu verdanken, dass Diaspora und speziell Diasporakultur als solch offen texturierte Konzepte gedacht werden können. Diaspora fordert gleichwohl Konzepte von Kultur immer wieder aufs Neue heraus. 


\subsubsection{Jenseits von Hybridität}

Die Valorisierung von Differenz gegenüber Diversität und die Definition von Kultur als Differenz und nicht als homogenes Amalgam führt Homi K. Bhabha zu der Schlussfolgerung: „The theoretical recognition of the split-space of enunciation may open the way to conceptualizing an international culture, based not on the exoticism of multiculturalism or the diversity of cultures, but on the inscription and articulation of culture's hybridity“ (56). Hybridität wiederum, heißt es weiter, ist die „precondition for the articulation of cultural difference“ (ebd.). Diese Dialektik ermöglicht es, Hybridität nicht als bloße Vermischung verschiedener kultureller Elemente, sondern als vielschichtige Formation von Kultur zu begreifen: „All forms of culture are continually in a process of hybridity“ (Rutherford 211). Im Zusammenhang mit Diaspora ist Hybridität zum beliebten Begriff der Analyse und Beschreibung geworden. Er bezeichnet alle möglichen Varianten der Vermischung und Kombination verschiedener Elemente im Moment des kulturellen Austausches. Im Zusammenhang mit Diaspora wird Hybridität zumeist als Prozess gesehen, in dem die in der Diaspora Ankommenden Elemente der Ankunftsgesellschaft annehmen und zu einer neuen hybriden Kultur umwandeln. Diese hybriden Kulturen erwachsen aus einer permanenten Dialektik zwischen dem Annehmen der und Abgrenzen gegen die Kultur des Ankunftslandes. Der Kultur- und Kommunikationswissenschaftler Nikos Papastergiadis nennt dies „twin processes of globalization and migration“ (3). Hybridität wird damit zu einem beweglichen Verbindungsglied kultureller Produktionen.

Die positive Besetzung des Hybriditätsbegriffes geriet, ob seines Ursprunges aus den Fächern der Naturwissenschaft, wo er die Vermischung zweier Arten beschreibt, schnell in die Kritik. Robert Youngs historisch geleitete Forschung 
kritisierte entsprechend die Mutation des Begriffes von seinen Ursprüngen aus der Evolutionstheorie des neunzehnten Jahrhunderts zum Leitbegriff des Postkolonialismus des späten zwanzigsten Jahrhunderts. Der Hybriditätsgedanke im Zusammenhang mit Kultur würde voraussetzen, dass es „ursprüngliche Kulturen“ gäbe, aus denen etwas Hybrides entstehen könnte. Gegen diese Engführung spricht er sich dezidiert aus:

Whether the process of mixture is presented as fatal or redemptive, we must be prepared to give up the illusion that cultural and ethnic purity has ever existed, let alone provided a foundation for civil society. The absence of an adequate conceptual and critical language is undermined and complicated by the absurd charge that attempts to employ the concept of hybridity are completely undone by the active residues of that term's articulation within the technical vocabularies of nineteenth-century racial science. $(50-51)$

Die Leistung der Cultural wie Postcolonial Studies ist es meines Erachtens, gerade jene Essentialismen von Identität, Ethnie und Kultur, welche bis dato vorherrschend waren, aufzuweichen. Hybridität bietet ein mögliches Konzept dafür und setzt eben keine ,reinen“ Kulturen voraus, sondern zelebriert die Kontaktzonen und Übergänge. Der Philosoph Wolfgang Welsch bekräftigt seinerseits mit seinem Konzept der Transkulturalität „ein vielmaschiges und inklusives, nicht separatistisches und exklusives Verständnis von Kultur“ (75). Dem zugrunde liegt die Annahme, dass „Kulturen jenseits des Gegensatzes von Eigenkultur und Fremdkultur zu denken“ (69) sind und „eine Vielzahl von Lebensformen und Kulturen einander auch durchdringen oder auseinander hervorgehen können“ (71). Hybridität verstanden nicht nur als Vermischung, sondern auch als Durchdringung und Überwindung von Kultur und kulturellen Zuschreibungen, bietet so ein durchaus interessantes Konzept für die Auseinandersetzung mit Diaspora. 
James Clifford knüpft 1994 in seinem Text „Diasporas“Kultur und Diaspora eng aneinander und spricht dabei von hybriden diaspora cultures: „Diaspora cultures work to maintain community, selectively preserving and recovering traditions, ,customizing' and ,versioning' them in novel, hybrid, and often antagonistic situations“ (317). Er distanziert sich dabei dezidiert, ähnlich wie Stuart Hall, von essentialistischen Zuschreibungen von Kultur im Allgemeinen und von Diasporakultur im Speziellen: „As counterdiscourses of modernity, diaspora cultures cannot claim an oppositional or primary purity“ (319). James Clifford plädiert für einen Diasporabegriff, der Momente von Hybridität einschließt: „Diaspora communities, constituted by displacement, are sustained in hybrid historical conjunctures“ (315) und folgt damit einschlägigen Theorien wie jenen von Geschichtswissenschaftler Kobena Mercer, der von „the hybridized terrain of diasporic culture“ (254) spricht, oder Avtar Brah, die Hybridität als „,a key concept within cultural criticism" (Brah und Coombes, Cover) einordnet, ohne jedoch auf eine modellhafte Wirkung abzielen zu wollen. Clifford kritisiert vor allem jene Definitionen von Diasporakultur, welche hauptsächlich den Bezug zum Herkunftsland in den Vordergrund stellten, und warnt: „But we should be wary of constructing our working definition of a term like diaspora by recourse to an ,ideal type “ [...]“ (306). Wo Bhabha Diasporakultur und postkoloniale Kultur gleichsetzt, spricht sich Clifford für den feinen Unterschied zwischen den Begriffen Hybridität und verwandten Konzepten wie mestizaje oder créolité aus: „These are not identical concepts, and they emerge from distinct historical situations; but they overlap and together denote a domain of complex cultural formations produced by, and partially subverting, colonial dichotomies and hierarchies“ (330). Auch findet er, dass zwar von „diasporic culture“, jedoch nicht von „postcolonial culture“ gesprochen werden kann: „There are no postcolonial cultures or places: only moments, tactics, discourses, and so forth“ (328). Sein Hyb- 
riditätsbegriff ist stark beeinflusst von jenem Homi K. Bhabhas, der den Begriff Hybridität ebenfalls nicht benutzt, um vorherrschende Binaritäten zu bestätigen: „Hybridity [...] is not a third term that resolves tension between two cultures“ (Bhabha 162). Ihm dient der Begriff dazu, Kultur in eine Vielzahl an Positionen und Perspektiven aufzulösen sowie Überlappungs- und Überschreibungsmechanismen sichtbar zu machen: „The importance of hybridity is not to be able to trace two original moments from which the third emerges, rather hybridity [...] is the ,third space" which enables other positions to emerge" (Rutherford 211). Mit James Clifford argumentiert, meint Diasporakultur eben diese Entstehung anderer, alternativer Positionen, nicht die Vermischung zweier statischer kultureller Räume, sondern die Ansammlung aller - positiver wie widersprüchlicher und konfliktgeladener - Lebenserfahrungen.

In diesem Sinne argumentiere ich, dass Hybridität nicht den End-, sondern den Ausgangspunkt von Diaspora bildet. Hierzu sei auf Arjun Appadurai verwiesen, der in seinem Text „How Histories Make Geographies“ bekräftigt: „Crucial to an understanding of cultural flows is the relationship between the forms of circulation and the circulation of forms“ (9). Anknüpfend distanziert er sich dabei von Formen willkürlicher Hybridität und postuliert ein Beiwohnen, eine Verschränkung und Verflechtung unterschiedlicher Formen: „We need to move decisively beyond existing models of creolization, hybridity, fusion, syncretism, and the like, which have largely been about mixture at the level of content. Instead, we need to probe the cohabitation of forms“ (10). Dem zugrunde liegt eine Revision seines Konzepts der ethno- beziehungsweise mediascapes - seinesgleichen bereits auf Ströme und Beziehungsgeflechte angelegt - hin zu gesteigerten dynamischen Wechselbeziehungen: 
Therefore, recognizing that circulation itself has some formal properties, mainly in terms of time, space, and scale, I would modify my earlier argument that the uneven relationships between a variety of scapes - I used the term ,ethnoscapes ${ }^{6}$ - produced these junctures and differences in the global cultural economy. Today, I would make that suggestion more dynamic by arguing that the bumps and blocks, disjunctures and differences are produced by the variety of circuits, scales and speeds, which characterize the circulation of cultural elements. (11)

Mit diesem offenen und flexiblen Begriff von Kultur, präziser von Diasporakultur, ist im Folgenden das Erkenntnisinteresse verknüpft, zu ergründen, „what it is Iranians are and experience as a result of having left Iran“ (Elahi und Karim 382).

\subsection{Diaspora und Iran}

Iran hat, wie die meisten heutigen Nationalstaaten, eine lange Migrationsgeschichte. Bereits im achten Jahrhundert flohen Anhänger_innen des Zoroastrismus nach der arabisch-muslimischen Kolonisierung aus Iran ins benachbarte Indien, um religiöse Freiheit zu leben. Im neunzehnten Jahrhundert gingen wiederum viele Iraner_innen ins benachbarte russische Zarenreich, um dort in der Ölindustrie zu arbeiten. Nach dem Zweiten Weltkrieg schlossen sich viele jüdische Iraner_innen dem neu gegründeten Staat Israel an. In der zweiten Hälfte des zwanzigsten Jahrhunderts gingen viele Iraner_innen der mittleren und oberen sozialen Schichten in Länder wie Deutschland, Frankreich, Großbritannien, Österreich und die Vereinigten Staaten, um zu studieren. Ihr Ziel war es, mit dem gelernten Wissen nach Iran zurückzukehren (Raji 193). Das Jahr 1979 markiert 
eine Zäsur in der jüngsten iranischen Geschichte: Die islamische Revolution, die die Absetzung des Schahs Reza Pahlavi und die Einrichtung einer islamischen Republik unter Ayatollah Khomeini zur Folge hatte, führte zur wohl größten Emigrationswelle, die das Land je gesehen hat. Migrationswellen aus Iran nahmen ihren Anfang bereits in den 1960er Jahren, um dem repressiven SchahRegime zu entfliehen. Die Folgen der islamischen Revolution und des Golfkrieges zwischen Iran und Irak hinderten auch Menschen der ersten Welle daran, nach Iran zurückzukehren, und so kam es zu einem beträchtlichen brain drain:

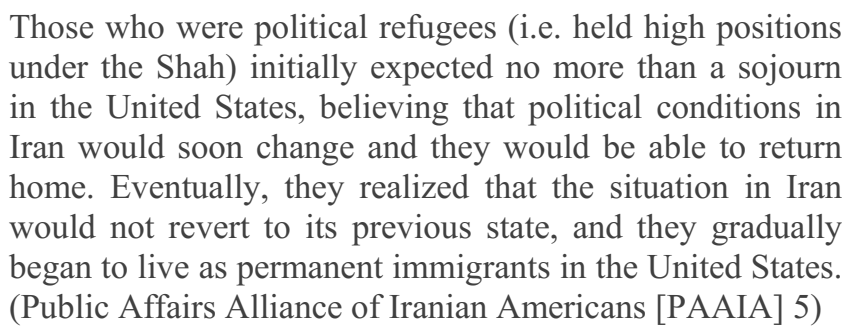

Weitere Migrationswellen folgten in den 1990er Jahren und vermehrt nach den Aufständen der grünen Bewegung im Jahr 2009. Eine genaue Gesamtzahl aller außerhalb Irans lebenden Iraner_innen gibt es derzeit nicht, diese wird aber auf vier bis sechs Millionen Menschen geschätzt (Vahabi). Der Großteil der Iraner_innen ging nach Nordamerika, dicht gefolgt von Europa und Australien, mit den großen Städten als Hauptdestinationen. Iraner_innen gingen auch in andere Länder beziehungsweise Städte der MENA-Region wie Istanbul, Doha oder Dubai, welche vor allem als Wirtschaftsstandorte attraktiv geworden sind.

Die Forschung zu diesen Migrationsbewegungen kommt mehrheitlich aus den Vereinigten Staaten, wo auch eine Vielzahl an Institutionen gegründet wurde: Das National Iranian American Council (NIAC) vertritt seit 2002 die Interes- 
sen iranisch-amerikanischer Bürger_innen im Capitol Hill; Iranian Alliances Across Borders (IAAB) ist ein nicht-politischer und nicht-religiöser Verein, der sich seit 2004 die Vernetzung von Iraner_innen außerhalb Irans zum Ziel gesetzt hat $^{29}$ (in Europa verfolgen Vereine wie Safran in Österreich oder DIWAN in Deutschland ähnliche Ziele), und in Großbritannien sind Stiftungen wie die Iran Heritage Foundation und Magic of Persia um die Erhaltung und Verbreitung des kulturellen und historischen Erbes Irans bemüht. ${ }^{30}$ Die Public Affairs Alliance of Iranian Americans hebt hervor: „When compared to other refugee groups in the United States (except for Cuban and Vietnamese immigrants), the overall socioeconomic background of these immigrants was quite high“"(5). Diese Aktivitäten erklären sich also unter anderen aus dem Umstand, dass es vor allem Iraner_innen der sozial mittleren bis hohen Schichten waren, die Iran verlassen haben und ihr Kapital und Wissen mitnahmen.

\subsubsection{Vom Exil zur Diaspora}

Um erneut Nilou Mostofis Frage aufzuwerfen: „Why is Iranian immigration even termed a diaspora?“ (685), ist zunächst die Unterscheidung zu anderen Begriffen im Migrationskontext in den Blick zu nehmen. Die (Selbst)Bezeichnung von im Ausland lebenden Iraner_innen als „diasporic“ oder schlicht als „Diaspora“ ist eine interessante und durchaus rezente Entwicklung. Vorherrschend waren sowohl im populären Diskurs als auch in der Forschung zunächst vor allem die Begriffe „Flüchtling“, „Émigré“ und „Exil“, doch dies änderte sich und Iraner_innen ,reinvented themselves as a distinct national and ethnic group outside of Iran. [...] A move away from the urgency of an exilic and immigrant narrative to one that situates Iran and Iranian culture in the continuum of more global diasporic consciousness“" (Elahi und Karim 382-84). 
Den Anfang machten der Iranist Georges Sabagh und der Soziologe Mehdi Bozorgmehr in ihrer 1987 veröffentlichten Studie „Are the Characteristics of Exiles Different from Immigrants? The Case of Iranians in Los Angeles“. Darin untersuchen sie in Los Angeles lebende Iraner_innen vor und nach 1979. Die Studie ist quantitativ orientiert und interessiert sich wenig für konzeptuelle Begriffsarbeit, möchte aber den Unterschied zwischen Immigrant_innen und Exilant_innen durch deren Berufswahl und Einkommen herauskehren. Asghar Fathi, ebenfalls Soziologe, setzt 1991 mit der Herausgabe von Iranian Refugees and Exiles since Khomeini einen anderen Akzent. Er bettet die für die damalige Zeit neue Situation in eine längere historische Entwicklung ein und betrachtet das Phänomen interdisziplinär. Der Begriff Diaspora kommt dabei zwar kein einziges Mal vor, die Komplexität der Erfahrungen außerhalb des Herkunftslandes wird jedoch deutlich dargelegt. Weitere Publikationen, die den Diasporabegriff in den Forschungen der letzten zehn Jahre zu außerhalb Irans lebenden Menschen stark machen, sind beispielsweise Exiled Memories: Stories of Iranian Diaspora der Literaturwissenschaftlerin Zohreh T. Sullivan, „Who We Are: The Perplexity of Iranian-American Identity“ der Soziologin Nilou Mostofi und Let Me Tell You Where I've Been: New Writing by Women of the Iranian Diaspora der Iranistin Persis M. Karim. Exil, so der Philosoph Farhang Erfani, sei eine „negative form of resistance“ (Iranian Cinema 168), und auch Hamid Dabashi bekräftigt:

More often than not, these ,oppositional' intellectuals degenerate into irrelevant parasites with no organic link either to their presumed ,homeland" or to their immediate physical surroundings. They end up living in a cocoon, a hermetic sea of suffocating limitations. They increasingly grow irrelevant to the changing configuration of reality-bitter, reclusive, morally and intellectually isolated from their environment. (257) 
Im Gegensatz dazu hebt die Public Affairs Alliance of Iranian Americans die zunehmend gute Integration von Iraner_innen im Gegensatz zu beispielsweise der chinesischen oder indischen Diaspora in den Vereinigten Staaten hervor:

However, the pattern of settlement of Iranians has not re-
sulted in a geographically segregated ethnic neighborhood,
defined by a dense area in which local ethnic businesses ca-
ter mostly to other co-ethnics, and co-ethnics live close to-
gether in residentially segregated areas (such as for exam-
ple, Chinatown). (14)

Dieser Umstand führt, so die Public Affairs Alliance of Iranian Americans weiter, zu folgender Entwicklung: „Iranians are now at a point in their immigrant journey where they selectively choose elements of their Iranian and American

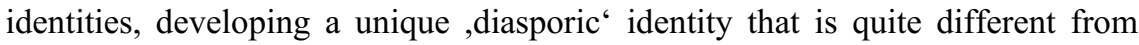
native Iranians“ (11). Auch Babak Elahi und Persis M. Karim heben hervor:

Iran's current diaspora is by necessity part of a longer continuous historical narrative in which Iranian peoples have adapted and reinvented themselves. It is not only the home culture that determines the direction of diaspora. Rather, the complex network of places and spaces of home and away are mutually transformative. (387)

Neben diesen sozialwissenschaftlichen Ansätzen sind es vor allem die kulturwissenschaftlichen Forschungen Hamid Dabashis zum Theaterschaffen von Parviz Sayyad und Hamid Naficys zur TV- und Radiolandschaft von Los Angeles 1993, die einen gewichtigen Beitrag zur (Selbst-)Bezeichnung „iranische Diaspora" geleistet haben. Hamid Dabashis Monographie Parviz Sayyad's Theater of Diaspora setzt den Begriff bereits prominent in den Titel. In seiner Einleitung spricht er von intergenerationellen Verbindungen zwischen Kunstschaffenden iranischen Ursprunges: „Before all the post-revolutionary anxieties 
of the disillusioned diaspora are artistically charted, before all the goblins damned of ,who lost the Revolution“ are exorcised, it may very well be that this generation of the Iranian artists abroad has led to the next" (Sayyad und Dabashi xi). Dabei impliziert er auch die dem Begriff der Diaspora innewohnende Charakteristik der Gemeinschaft. Hamid Naficy seinerseits arbeitet den Zustand der Liminalität und des Dazwischens heraus und spricht daher, trotz des Adjektivs „exilic“ im Titel seiner Monographie The Making of Exile Cultures, von „an ethnic minority, not just an exilic community“ und „hyphenated IranianAmericans and not just Iranians“ (196) beziehungsweise schlussendlich von „people in diaspora“ (16-17). In seiner 2001 veröffentlichten Monographie $A n$ Accented Cinema: Exilic and Diasporic Filmmaking differenziert er weiter scharf zwischen Exil und Diaspora: „There is nothing common about exile and diaspora“ (3). Dies streicht auch Hamid Dabashi hervor, indem er den Begriff des Exils dekonstruiert, der in der Erfahrung und Lebensrealität von außerhalb Irans lebenden Menschen, speziell jenen in Los Angeles, einen zentralen Platz einnimmt:

The Iranian experience in Los Angeles, as a microcosm of their ,exilic' experiences everywhere, is a sad testimony to the violent power of words, when a rhetoric of isolationism robs reality of relevance: ,Iran', ,Home“, ,Exile‘. The sorry self-flagellation of a whole generation of people moaning in front of television shows, mourning their being ,in exile“ and away from their ,home ${ }^{6}$ is the symptom of a disease that refuses life. (248)

Die wiederholte (Selbst-)Bezeichnung „Exil“ schüre ein Narrativ, welches binäre Gegensätze forciert anstatt sie aufzulösen:

What jeremiad denials of life are these ,narratives of exile"?

No vision, no courage, no imagination of a life-affirming 
encounter with one's material life (wherever it might be) is evident in these sad, sorrowful pages of misery. Collapsing into the abyss of such sorry sentiments degenerates into a metaphysics of identity crisis that is simply pre-modern in its underlying assumptions. For all the presumptuous postmodernity of their rhetorical devices, these so-called ,narratives of exile' are positively medieval in their sentimental celebrations of an outdated crisis of identity, of such gross, historically untenable, binary oppositions presumed between ,home' and ,exile'. (249)

Diese Narrative und Rhetoriken von „Heimat“ und „Exil““ werden durch Familie und Popkultur auch an nächste Generationen weitergegeben. Dabashi sieht dabei das produktive Potenzial von diesen gut verdienenden und gut ausgebildeten Menschen außerhalb Irans vergeudet:

Instead of being a jubilant feast of freedom and possibilities otherwise denied at ,home', the Los Angeles carnival, representing all others, is a miserable mourning procession of an émigré sub-culture impotent to deliver itself from the mortifying memories of a past that never was, unable to face a present which could potentially be theirs, and incapable of imagining a future, visualizing a horizon that just might be their children's. (252)

Er entlarvt das Narrativ des Exils als Konstrukt, wenn er schließlich argumentiert, dass der Großteil außerhalb Irans lebender Menschen strikt gesehen gar nicht im Exil, sondern in einer Diaspora lebt:

The fact is that with few exceptions the overwhelming majority of Iranians living outside Iran can get on an airplane and return to their homeland and there lead a half-decent life not particularly worse or better than what they lead in Los Angeles, Washington DC, London, or Paris. (251) 
Hamid Naficy widmet 2012 einen ganzen Band seiner vierbändigen Monographie $A$ Social History of Iranian Cinema der iranischen Diaspora und deren Filmschaffen. Darin ist der Begriff der Diaspora omnipräsent. Er schreibt von „Iranian culture in the diaspora“ (The Globalizing Era 384) beziehungsweise von einer ,worldwide diaspora“ (372) und besetzt den Begriff eindeutig positiv:

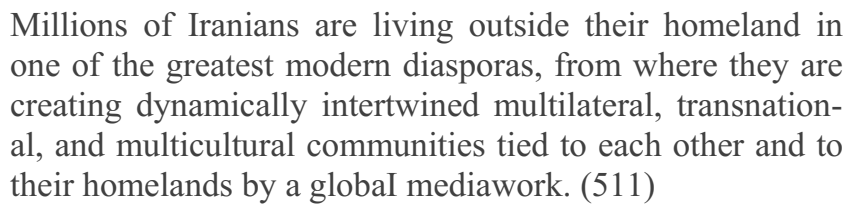

Der Unterschied zwischen „Exil“ und „Diaspora“ liegt seiner Meinung nach auf dem Bezugspunkt beziehungsweise Referenzrahmen. „Exil““ würde diesen eng an das Herkunftsland Iran knüpfen, wohingegen „Diaspora“ die Öffnung hin zum derzeitigen Lebensmittelpunkt und die Koexistenz verschiedener Einflüsse eindenkt:

While the exiles' identity involved a near exclusive, verti-
cal relationship with the Iranian homeland, diasporic con-
sciousness was multisited and multilateral: a vertical rela-
tionship with Iran and horizontal relations both with Iranian
compatriot communities elsewhere and with their coethnics
and coreligionists across the globe. (395)

Diesen Umstand führt Naficy auf die Tatsache zurück, dass Iran keine Kolonie war und daher auch keine postkoloniale Identitätsbildung außerhalb des Herkunftslandes möglich gewesen sei (383). Ähnlich wie Dabashi argumentiert auch er, dass der Wandel von „Exil““ zu „Diaspora“ etwas mit den praktischen Rückkehrmöglichkeiten zu tun hat: „Finally, as exile became diaspora and immigration, and as more Iranians returned home for visits, the sights and sounds of home 
of decades earlier lost their hold“ (388). Wichtig dabei ist ihm nach wie vor, die Komplexität und Heterogenität der iranischen Diaspora herauszustreichen:

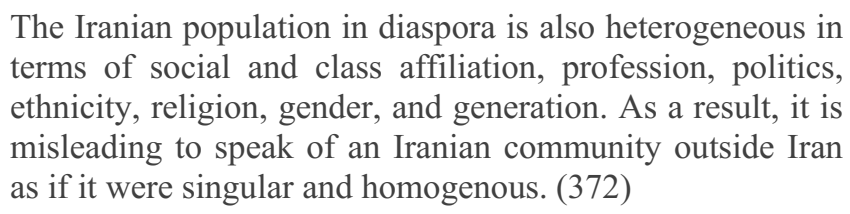

Die Institutionalisierung der Iranian Diaspora Studies bildet den vorläufigen Endpunkt dieser Entwicklung. Das 2016 gegründete Center for Iranian Diaspora Studies an der San Francisco State University unter der Leitung von Persis M. Karim möchte der Frage nach dem Einfluss von Massenmigration durch Kunst und Kultur nachgehen und damit einen innovativen Beitrag zu Studien rund um die iranische Diaspora, ihre Entwicklung und Identität anstoßen. ${ }^{31}$ Es ist das erste Zentrum, welches seine Forschung dezidiert ausschließlich der iranischen Diaspora widmet.

\subsubsection{Ethnizität als Marker}

Die Verlagerung der Bezeichnungen „Flüchtling“, „Immigrant“ und „Exil“ hin zu „Diaspora“ ist im Kontext der Erweiterung des Begriffes Diaspora und der daraus resultierenden Diaspora Studies zu sehen und schließt an den Wandel von einem negativ besetzten Begriff einer spezifischen Form der Zerstreuung zu einem flexiblen und positiv besetzten Konzept globaler Migrationsbewegungen an. Die iranische Diaspora ist hierbei, wie jede Diaspora, keineswegs eine kohärente Gemeinschaft. Sie beinhaltet Menschen verschiedener politischer Couleur, sozialer Herkunft und Generationen.

Problematisch an dem Begriff ,iranische Diaspora“ ist das Adjektiv, welches die ethnische Zuschreibung sichtbar macht und damit einer Inklusions- 
beziehungsweise Exklusionslogik folgt. Im Wörterbuch für Ethnologie wird Ethnizität als Konzept einer Menschengruppe mit einheitlicher Kultur und Identität beschrieben (Streck 53). Dieser allzu simplen, lange vorherrschenden, Definition hält Stuart Hall in seinem Text „Old and New Identities, Old and New Ethnicities“"Folgendes entgegen:

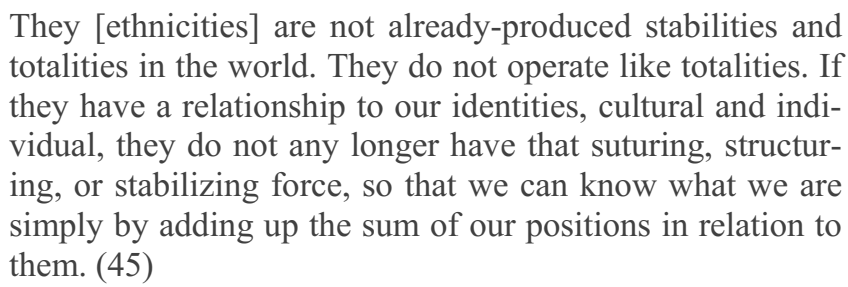

Eng geknüpft an das Konzept von Identität als nie abgeschlossener Prozess „identities are never completed, never finished; [...] they are always as subjectivity itself is, in process“ (47) - ist auch Ethnizität keine in sich abgeschlossene Entität. Der Prozess von Identität zu ethnischer Identität verläuft, laut Stuart Hall, über Identifikation und Inklusions- beziehungsweise Exklusionsmechanismen. Diese Mechanismen spielen vor allem bei der Suche nach identitätsformenden Narrativen eine große Rolle:

In the course of the search for roots, one discovered not only where one came from, one began to speak the language of that which is home in the genuine sense, that other crucial moment which is the recovery of lost histories. The histories that have never been told about ourselves that we could not learn in schools, that were not in any books, and that we had to recover. (52)

Diese Narrative sind es, die das Bewusstsein für Zugehörigkeiten und (Selbst)Zuschreibungen formen. Stuart Hall führt dabei das Beispiel jamaikanischer Menschen an, die auf die Frage hin, ob sie sich selber als „Schwarz“ bezeichnen 
würden, zunächst befremdet reagiert hätten. Die verschiedenen Abstufungen der Hautfarben von Braun und Schwarz waren in der jamaikanischen Sprache durch viele verschiedene Begriffe verankert, eine einzige Kategorie gab es dazu allerdings nicht. Dies entstand erst im Zuge des Postkolonialismus, als Ermächtigung und Abgrenzung gegenüber den weißen Kolonialmächten. Stuart Hall beschreibt daher die Kategorie „Schwarz“ wie folgt: „The Black I'm talking about is a historical category, a political category, a cultural category“ („Old and New Identities“ 53), und weiter: „Black was created as a political category in a certain historical moment. It was created as a consequence of certain symbolic and ideological struggles“ (54). „Schwarz“ ist also eine Kategorie, die zu einem bestimmten historischen Zeitpunkt an einem bestimmten geographischen Ort eine ethnische Zuschreibung kreiert. Sichtbar gemacht werden dabei in einem Akt der In- beziehungsweise Exklusion vor allem ein Machtverhältnis, eine Valorisierung oder Ermächtigung gegenüber einem Anderen:

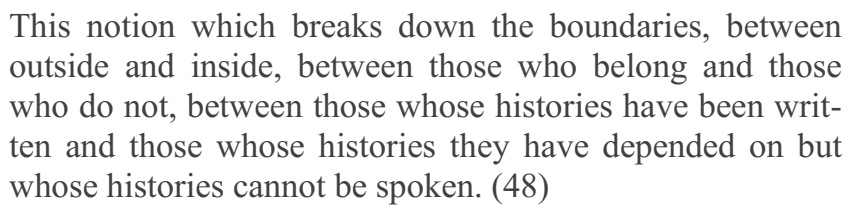

Mit Stuart Hall möchte ich argumentieren, dass der Begriff „,iranische Diaspora“ - ebenso wie das von ihm angeführte Beispiel „Black“ - eine konstruierte Kategorie ist, die einem spezifischen sozio-politischen und historischen Kontext entspringt. Die islamische Revolution und die damit verbundenen Migrationswellen zum Ausgangspunkt (gleichsam als Stunde null) nehmend, ist der Begriff mit dem Wunsch einer Positiv-Beschreibung aufgeladen. Damit verbunden ist das Bild des wohlintegrierten, linken, anti-religiösen, gebildeten und westlich orientierten Menschen der mittleren bis oberen sozialen Mittelschicht, 
der global sowohl mit Iran als auch mit allen anderen Menschen innerhalb der iranischen Diaspora und seines jeweiligen Lebensraumes vernetzt ist. Dies führt die Illusion einer homogenen Identität mit sich, die es so natürlich nie gibt: „The notion that identity has to do with people that look the same, feel the same, call themselves the same, is nonsense“ (Hall, „Old and New Identities“ 49). Dieser Trend zu ethnischen (Selbst-)Zuschreibungen ist jedoch durchaus auch kritisch zu sehen, so Stuart Hall weiter:

In that moment, the enemy was ethnicity. The enemy had to be what we called ,multi-culturalism'. Because multiculturalism was precisely what I called previously, the exotic $^{6}$. The exotica of difference. Nobody would talk about racism but they were perfectly prepared to have ,International Evenings', when we would all come and cook our native dishes, sing our own native songs and appear in our own native costume. (55-56)

Die Faszination des Westens für das Exotische steht im Kontrast zu fremdenfeindlichen Diskursen, die nicht zuletzt auf koloniale Machtstrukturen zurückzuführen sind. Die Kategorie des Exotischen kann hierbei jedoch nicht mehr ausschließlich als Projektion orientalistischer Phantasien des Anderen ausgehend von einem Zentrum verstanden werden, sondern muss über traditionelle OstWest-Binaritäten hinaus ausgeweitet werden. Manifestationen des Exotischen gehen von mehreren Orten aus und sind in dieser Perspektive multidirektional zu verstehen. In diesem Sinne ist der Begriff „,iranische Diaspora“ nicht nur symptomatisch für eine positive Beschreibung einer bestimmten Erfahrung und Lebensrealität von außerhalb Irans lebenden Menschen in einem bestimmten historischen und geographischen Kontext. Sondern - und dies möchte ich hervorheben - Ethnizität wird hierbei als dezidiertes Mittel zur kulturellen Verortung eingesetzt, denn es ist die Frage „of positioning, of placing, which is what the term ethnicity connotes“ (Hall, „Old and New Identities“ 61), die hier virulent 
wird. Kulturelle Verortung hat demnach immer auch etwas mit Identität zu tun, denn diese findet, so Stuart Hall, nicht außerhalb, sondern innerhalb von Repräsentation selbst statt: „Identity is always in part a narrative, always in part a kind of representation. It is always within representation. Identity is not something which is formed outside and then we tell stories about it" (49). In diesem Sinne spiegelt sich das Verhältnis zwischen Iran, Diaspora und Repräsentation, als Teil kultureller Verortung, nicht zuletzt im medialen Schaffen wider. Ethnische Rundfunksendungen in Fernsehen und Radio, Zeitungen und Zeitschriften, aber auch soziale Medien bilden dabei einen Forschungsstrang ${ }^{32}$ - wie auch jener rund um den Diasporafilm.

Die Bezeichnung Iranian diasporic cinema führt, ähnlich wie Iranian diaspora selbst, die ethnische Zuschreibung als Marker kultureller Verortung immer mit. Darunter verstehe ich den Akt der Positionierung innerhalb eines kulturellen Feldes, in diesem Fall jenem des Filmes, wie ihn der Soziologe Pierre Bourdieu für literarische und künstlerische Werke beschrieben hat:

The space of literary or artistic position-takings, i.e. the
structured set of the manifestations of the social agents in-
volved in the field - literary or artistic works, of course, but
also political acts or pronouncements, manifestos or polem-
ics, etc. - is inseparable from the space of literary or artis-
tic positions defined by possession of a determinate quanti-
ty of specific capital (recognition) and, at the same time, by
occupation of a determinate position in the structure of the
distribution of this specific capital. (312; Hervorhebung im
Original)

Dieser Ansatz geht davon aus, dass solch eine Positionierung immer durch Aushandlungs- und Abgrenzungsprozesse zustande kommt: „The fact remains that every new position, in asserting itself as such, determines a displacement of the whole structure and that, by the logic of action and reaction, it leads to all 
sorts of changes in the prises de position of the occupants of the other positions" (338; Hervorhebung im Original). Wenn Ethnizität nun als kultureller Marker im Sinne eines placing oder prises de position/position-taking verstanden wird, was bedeutet dies dann für den Diasporafilm? Was wird hierbei wie und vor allem wo verhandelt? Die Sozialanthropologin Amy Malek analysiert in Anlehnung an Homi K. Bhabha in ihrem Text „Memoir as Iranian Exile Cultural Production: A Case Study of Marjane Satrapi’s Persepolis Series“ Marjane Satrapis Persepolis als ,a third space from which to question dominant notions in Western society regarding Iran and Iranian culture and history, and [...] an engaging forum from which to perform the important work of cultural translation from the Iranian diaspora“ (359) und ordnet Film damit dezidiert als einen gewichtigen kulturellen Ausdruck der iranischen Diaspora ein.

Filme stellen Differenzierungssysteme und kulturelle Praktiken dar und sind damit Teil gesellschaftlicher (Selbst-)Zuschreibungsprozesse und Bedeutungskonstruktionen. Was dies im Lichte der Verortung der iranischen Diaspora hinsichtlich des iranischen Diasporafilmes im Einzelnen und konkret heißt und wie neue diasporafilmische Räume wie „Zwischenräume“, „kosmopolitische Räume“ und „rebellische Räume“ zu verstehen sind, reflektieren die folgenden sechs Filmanalysen.

Open Access Dieses Kapitel wird unter der Creative Commons Namensnennung 4.0 International Lizenz (http://creativecommons.org/licenses/by/4.0/deed.de) veröffentlicht, welche die Nutzung, Vervielfältigung, Bearbeitung, Verbreitung und Wiedergabe in jeglichem Medium und Format erlaubt, sofern Sie den/die ursprünglichen Autor(en) und die Quelle ordnungsgemäß nennen, einen Link zur Creative Commons Lizenz beifügen und angeben, ob Änderungen vorgenommen wurden.

Die in diesem Kapitel enthaltenen Bilder und sonstiges Drittmaterial unterliegen ebenfalls der genannten Creative Commons Lizenz, sofern sich aus der Abbildungslegende nichts anderes ergibt. Sofern das betreffende Material nicht unter der genannten Creative Commons Lizenz steht und die betreffende Handlung nicht nach gesetzlichen Vorschriften erlaubt ist, ist für die oben aufgeführten Weiterverwendungen des Materials die Einwilligung des jeweiligen Rechteinhabers einzuholen.

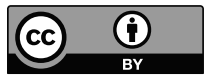

